Стойка В. С., доктор хабілітований Університет технологічно-природничий імені Я. С. Снядещьких в Бидгощі м. Бидгощ, Польща

DOI: https://doi.org/10.30525/978-9934-26-064-3-11

\title{
СУТНICТЬ ТА МЕТА ДЕРЖАВНОГО РЕГУЛЮВАННЯ ТУРИЗМУ
}

Туризм для багатьох країн світу є пріоритетним напрямом розвитку національної економіки, оскільки дана галузь здійснює позитивний мультиплікативний вплив на інші види економічної діяльності, сприяє притоку інвестицій, розбудові інфраструктури, 48 
розвитку торгівлі, зростанню зайнятості та збільшенню валового національного продукту загалом. Проблематиці розвитку туристичної галузі в Україні присвячено роботи Сисоєвої І.С. [5], Гаврилюка А.М. [6], Алексеєвої Ю.В. [7], Хлопяка С.В. [8], Cayx I.B. [10]. Окремі аспекти фінансування вітчизняної туристичної діяльності розглянуто також автором [11-13].

Необхідність державної підтримки та регулювання туризму як синтетичної, складної сфери діяльності й багатогранної економічної системи з розгалуженою мережею зв'язків, в орбіту якої входить понад 40 суміжних галузей національної економіки (транспорт, зв'язок, харчування), є очевидною. Необхідність впливу органів державної влади на розвиток туризму доведена світовою практикою. Зокрема, в Гаазькій декларації по туризму зазначено, що туризм має плануватися державною владою на комплексній і послідовній основі з урахуванням усіх аспектів цього феномена $[1$, c. 58]. Згідно 3 позицією Всесвітньої туристичної організації, на сучасному етапі розвитку туризму тільки держава й уряд відіграють першорядну, якщо не єдину, роль, а всі інші учасники лише долучаються [2, с. 222].

Аналіз, проведений Всесвітньою туристичною організацією (ВТО), свідчить, що у більшості країн світу державна туристична політика впроваджується безпосередньо через центральні органи виконавчої влади - національні туристичні організації, інші інститути, а також опосередковано за допомогою правових важелів підтримки туристичної інфраструктури та міжнародної політики. Туристична політика має характерні риси загальної політики держави. Разом із тим існують і деякі специфічні фактори, що впливають на ії формування: природні умови країни, розвиненість транспортної індустрії, соціальні фактори (умови життя людей, система відпусток); фактори, пов'язані зі створенням економічної основи для розвитку туризму (стабільні валютно-фінансові, зовнішньоекономічні відносини); правові фактори, пов’язані зі створенням і функціонуванням туристичного законодавства. 
Законодавча основа державного регулювання туристичної діяльності в Україні складається з Конституції України, Закону України «Про туризм» від 15 вересня 1995 року № 324/95-ВР [3] та Закону України «Про курорти» від 5 жовтня 2000 року № 2026-III [4]. Цими Законами визначаються базові правові, організаційні, економічні та соціальні засади розвитку туризму та курортів. Закон України «Про туризм» визначає загальні правові, організаційні та соціально-економічні засади реалізації державної політики України в галузі туризму та спрямований на забезпечення закріплених Конституцією України прав громадян на відпочинок, свободу пересування, охорону здоров'я, безпечне для життя і здоров'я довкілля, задоволення духовних потреб та інших прав під час здійснення туристичних подорожей. Він встановлює засади раціонального використання туристичних ресурсів та регулює відносини, пов'язані 3 організацією і здійсненням туризму на території України [3]. Закон України «Про курорти» [4] визначає правові, організаційні, економічні та соціальні засади розвитку курортів в Україні та спрямований на забезпечення використання 3 метою лікування та оздоровлення людей природних лікувальних ресурсів, природних територій курортів, які є надбанням народу України, та їх охорони.

Згідно Закону України «Про туризм» [3] регулювання в галузі туризму здійснюється Верховною Радою України, Кабінетом Міністрів України, центральним органом виконавчої влади, що забезпечує формування державної політики у сфері туризму та курортів, місцевими державними адміністраціями, органами місцевого самоврядування, а також іншими органами в межах їх компетенції. Слід зазначити, що в національному законодавстві, a також серед вітчизняних дослідників відсутній єдиний підхід до розуміння поняття «державне регулювання туризму».

Зокрема, Сисоєва C.I. [5] під ним розуміє сукупність форм i методів цілеспрямованого впливу органів державної влади на діяльність суб'єктів господарювання та ринкову кон'юнктуру 3 метою забезпечення нормальних умов функціонування ринкового механізму, реалізації державних соціально-економічних 
пріоритетів, вироблення єдиної концепції розвитку туристичної сфери.

На думку Гаврилюка А.М. [6] під державним регулюванням туризму слід розуміти здійснення уповноваженими органами державної влади та органами місцевого самоврядування соціально-політичних, фінансово-економічних, правових, організаційних, інформаційних заходів, спрямованих на використання інноваційних підходів до розвитку вітчизняного туризму із застосуванням принципів державного маркетингу.

Алексеєва Ю.В. [7] вважає, що державне регулювання туризму представляє собою сукупність форм і методів цілеспрямованого впливу органів державної влади на розвиток туристичної сфери $\mathrm{i}$ створення умов для ефективної співпраці органів державної влади, місцевого самоврядування та приватного сектора щодо розвитку туризму через різні механізми (адміністративні, організаційні, економічні, правові, екологічні тощо).

Хлопяком С.В. [8] запропоновано розглядати механізм державного регулювання туризму як виважену систему прийомів, важелів та методів впливу на розвиток туризму в країні, а також способів їх практичного застосування за тієї чи іншої ситуації, якою обумовлюються цілі та завдання розвитку галузі.

На наш погляд, найбільш вдалим є означення державного регулювання туристичної діяльності, запропоноване Герасименко В.Г. та Михайлюком О.Л. [9], під яким слід розуміти систему дій та заходів держави щодо вибору i застосування сукупності інструментів, за допомогою яких здійснюється прямий або опосередкований вплив на об'єкти i суб'єктів туристичної діяльності та створюється сприятливе середовище для розвитку цього виду діяльності.

Виходячи $з$ наведеного означення, погоджуємося з Саух I.В. $[10$, c. 64], яка зазначає, що головною метою державного регулювання в туристичній індустрії $є$ : 1) створення конкурентноспроможного та високоефективного туристично-рекреаційного комплексу, спроможного забезпечити задоволення потреб вітчизняних i закордонних громадян у туристичних 
послугах, здійснити вагомий внесок у розвиток економіки країни i регіону за рахунок збільшення кількості робочих місць, податкових надходжень до бюджету; 2) підвищення ефективності використання потенціалу туристично-рекреаційного комплексу України в контексті побудови соціально орієнтованої економіки.

\section{Література:}

1. Мельниченко О.А., Шведун В.О. Особливості розвитку індустрії туризму в Україні: монографія. Харків : Вид-во НУЦЗУ, 2017. 153 с.

2. Шелеметьєва Т.В. Особливості та проблеми державного регулювання розвитку туризму в Україні. Глобальні та національні проблеми економіки. 2019. Випуск 21. С. 221-225.

3. Закон України «Про туризм» від 15 вересня 1995 року № 324/95-ВР. URL: https://zakon.rada.gov.ua/laws/show/324/95-вр\#Text.

4. Закон України «Про курорти» від 5 жовтня 2000 року № 2026-III. URL: https://zakon.rada.gov.ua/laws/show/2026-14\#Text

5. Сисоєва С.I. Механізми управління туристичним бізнесом в Україні. Актуальні проблеми державного управління: зб. наук. пр. Харків : Видавництво ХарРІ НАДУ «Магістр», 2014. № 2. С. 75-80.

6. Гаврилюк А.М. Державне регулювання комунікаційного забезпечення туристичної індустрії в Україні: автореф. дис. ... к.держ.упр.: спец. 25.00.02 «Механізми державного управління». Київ, 2011.23 с.

7. Алєксєєва Ю.В. Державне регулювання розвитку туристичної галузі України в контексті досвіду Франції: автореф. дис. ... к.держ.упр.: спец. 25.00.02 «Механізми державного управління». Одеса, 2005. 20 с.

8. Хлопяк С. В. Державне регулювання туризму в Україні: автореф. дис. на здобуття наук. ступеня канд. ек. наук: спец. 08.00 .03 «Економіка та управління національним господарством». Київ, 2015. 27 с.

9. Державне регулювання сфери туризму України в контексті процесів євроінтеграції. За заг. ред. В.Г. Герасименко, О.Л.Михайлюк. Київ : ФОП Гуляєва В.М., 2019. 332 с.

10. Саух І.В. Державне регулювання розвитку туризму: сутність, поняття та проблеми визначення. Актуальні проблеми економіки. 2014. № 4 (154). C. 59-66.

11. Стойка В.С. Розвиток та функціонування кооперативних банків: зарубіжний досвід. Теоретичні $i$ практичні аспекти економіки та інтелектуальної власності. 2013. Вип. 2. С. 165-170.

12. Стойка В.С. Основні тенденції і напрями розвитку банківського сектору Закарпатської області. Науковий вісник Полтавського університету економіки $i$ торгівлі. 2013. Вип. 1 (56). С. 305-313. 
13. Стойка В.С. Міжнародний досвід функціонування державних банків розвитку: уроки для України. Вісник Одеського наџіонального університету ім. I.I. Мечникова. 2017. Вип. 3 (56). Том. 22. С. 157-161. 